\title{
SOCIO-PROSTORNI PRISTUP DEFINIRANJU I ISTRAŽIVANJU OTPORNOSTI I ODRŽIVOSTI
}

\author{
Jelena Zlatar Gamberožić, Sara Ursić i Jana Vukić
}

\author{
Jelena Zlatar Gamberožić \\ Institut za društvena istraživanja u Zagrebu \\ Frankopanska 22, 10000 Zagreb \\ e-mail: zlatar.jel@gmail.com \\ Sara Ursić \\ Institut društvenih znanosti Ivo Pilar \\ Trg Marka Marulića 19, 10000 Zagreb \\ Jana Vukić \\ Filozofski fakultet Sveučilišta u Zagrebu \\ Ivana Lučića 3, 10000 Zagreb
}

\begin{abstract}
Sažetak
U posljednjih nekoliko desetljeća koncept održivosti etablirao se kao dio društvenih znanosti. Unatoč činjenici da je proizašao iz ekološke paradigme, ekološka je dimenzija samo jedan od četiriju stupova održivosti te tek zajedno sekonomskim, socijalnim $i$ kulturnim stupom čini temelj onog što danas nazivamo održivim razvojem. Na sličan način možemo sagledavati i pojam otpornosti koji, pozicioniran u širi kontekst socio-ekološkog sustava često predstavlja odgovor na ekološke, elementarne ili biološke katastrofe. Primarna surha analize $i$ evaluacije koncepata otpornosti $i$ održivosti u ovome radu jest pokušaj postavljanja integrativnog teorijskog okvira za istraživanje urbanih i ruralnih prostora i lokalnih zajednica iz sociološke perspektive. Definiranjem i analizom ovih koncepata, razgraničavanjem njihovih razlika i promišljanjem urbane otpornosti, otvara se mogućnost detaljnijeg i konkretnijeg daljnjeg istraživanja otpornosti. Razumijevanje prostorne, socijalne i kulturne otpornosti u uskoj je vezi s konceptom zajednice kao aktera u tom dinamičnom procesu. Pogotovo je u kontekstu socijalne otpornosti kao alata za unaprjeđenje (ruralnog $i$ urbanog) prostora koncept zajednice od presudne važnosti za razumijevanje suvremenih socio-prostornih odnosa. Pritom su prostornost $i$ lokalnost zajednice vrlo bitni aspekti promišljanja kojima se konstruiraju $i$ preispituju neke nove dimenzije zajednica. Lokaliziranje otpornosti i održivosti dogada se upravo u zajednici bilo da je riječ o prostornoj ili kulturnoj lokalizaciji.
\end{abstract}

Ključne riječi: održivost, urbana otpornost, prostorna otpornost, kulturna otpornost, otpornost zajednica

\section{UVOD}

Održivost i otpornost kao koncepti otvoreni su za višestruku, ponekad kontradiktornu interpretaciju, koja se dijelom shvaća kao snaga jer potiče rasprave između različitih disciplina koje se ovim konceptima bave, ali često se događa da se društvenim znanostima nameće istraživački okvir tehničkih ili prirodnih znanosti. Supstancijalna bliskost ovih 
dvaju koncepata i spomenuta otvorenost zahtijevaju pojačan napor kako bi se različiti pristupi njihovom istraživanju sagledali, usporedili i međusobno povezali u koherentnu znanstvenu cjelinu. O ovim pojmovima i njihovim definicijama pišu mnogi autori (npr. Yamagata i Mayurama, 2016; Begg i sur., 2015; Kuhlicke, 2013; Rink i sur., 2014; Kabisch i sur., 2018). Neki se autori posebno fokusiraju na razlike između ovih pojmova pri čemu se uglavnom naglašavaju njihovi različiti vremenski okviri, akteri na koje pojedini koncept stavlja naglasak te prostorne i vremenske dimenzije koje pojedini koncept obuhvaća (Burayidi i sur., 2020).

Ovaj se $\operatorname{rad}^{1}$ fokusira na urbanu / prostornu otpornost i održivost u društvenim znanostima s naglaskom na socijalnu otpornost, te se definira kroz prostornu otpornost, konkretnije otpornost zajednice i kulturnu otpornost. Upravo su ove dimenzije otpornosti one na koje smo, u kontekstu društvenih znanosti, željeli staviti poseban naglasak i pobliže ih teorijski objasniti. Otpornost i održivost važno je i nužno promatrati kroz prizmu zajednice i kulture kao važnih dvaju dimnezija održivosti (socijalne i kulturne), a koje su još uvijek nedovoljno obrađene, pogotovo u hrvatskom kontekstu. Uz ostale dimenzije održivosti (ekološku i ekonomsku), one tvore cjelokupan koncept održivosti te smo ovim radom željeli približiti njihove ključne odrednice i konceptualizirati ih. Uzimajući u obzir navedeno, u diskurs otpornosti neminovno je dakle uključiti i društvenu, kulturnu i prostornu otpornost kao stupove koji zajedno omogućavaju održivost otpornosti. Ovim su se pojmovima bavili različiti teoretičari u pokušaju da kontekstualiziraju otpornost kao rezultat odgovora na dugoročne izazove $s$ kojima se susreću lokalne zajednice (Rega i Bonifazi, 2020; Bourbeau, 2018; Glavovic i sur., 2003). Uključivanjem prostorne otpornosti u diskurs o društvenoj otpornosti omogućava se povezivanje socio-ekološkog i socio-kulturnog sustava, dok kulturna otpornost produbljuje razumijevanje potencijalne otpornosti lokalne zajednice s obzirom na zajedničke vrijednosti i norme te predstavlja, između ostalog, normativni sistem otpornosti (Brunetta i Caldarice, 2020; Lucini, 2014; Panter-Brick, 2015).

Otpornost je pojam koji u hrvatskom kontekstu susrećemo više kao dio strategija i planova nego kao znanstveno-istraživački koncept, no također možemo izdvojiti neka istraživanja i autore koji se bave otpornošću u društvenim znanostima u Hrvatskoj posljednjih godina, a interes za istraživanje otpornosti raste i s obzirom na globalna događanja poput pandemije čime koncept otpornosti postaje jedan od ključnih istraživačkih interesa (Lukić i Tonković, 2018; Domazet i Župarić-Iljić, 2019; Krolo i sur., 2020; Vukić i sur., 2020; Brajdić Vuković i Doolan, 2021). Nadalje, imajući na umu događaje kojima svjedočimo na globalnoj (pandemija) i lokalnoj (potresi) razini, istraživanja otpornosti i održivosti pripadaju prioritetima društvenih znanosti par excellence zbog čega raste i potreba za konceptualizacijom tih pojmova u znanstvenom diskursu. Zato je također važno naglasiti na koje se načine provodi otpornost i koji su njezini najvažniji elementi.

1 Rad je nastao u sklopu znanstveno-istraživačkog projekta HRZZ-a „SECRURAL“ (UIP-2019-045257). Odluku o prihvaćanju rada za objavu donijela je izvršna urednica na temelju neovisnih double-blind recenzija. 
Kada govorimo o otpornosti socio-ekološkog sustavu ne govorimo samo o apstraktnom sustavu na koji utječu nepredvidive i neočekivane ekološke nedaće, već govorimo i o dugoročnim izazovima koji se događaju iznutra, odnosno proizlaze iz same zajednice koju pak moramo razumijevati u globalnom, ali i nacionalnom, regionalnom i lokalnom kontekstu. $U$ tom kontekstu važno je analizirati različite modele otpornosti zajednice uzimajući u obzir uvijek specifičan lokalni kontekst svake zajednice pri čemu se ostvaruju različiti modeli koje možemo primjenjivati kako u konkretnim primjerima zajednica, tako i kao putokaz za stvaranje novih modela (vidi: Ellis i Dietz, 2017; Jabareen, 2013; Pirlone i sur., 2020). Ovi se modeli bave načinima na koje se otpornost može inkorporirati u zajednicu i to najčešće kroz analizu: sustava vlasti i politike, različitih tipova aktera, fondova i mogućnosti financiranja, prirodnih resursa te alata otpornosti i narativa zajednice (Keck i Sakdapolrak, 2013; Cote i Nightingale, 2012; Gale i Bonzan, 2013). Neki gradovi se tako mogu nazvati otpornim gradovima (primjerice: Melbourne, Baltimore, Pittsburgh, Rim, Chicago, Orlando, Omaha, Atena, Amsterdam i dr.). Oni intenzivno rade na pojačanju vlastite otpornosti kroz različite modele i politike i to najvećim dijelom kroz povećavanje svojih ekoloških kapaciteta (gradskog zelenila poput parkova i šuma), kroz ekološko zbrinjavanje otpada, smanjenje potrošnje energije i ,zelenu“ izgradnju.

U radu će se kroz šest poglavlja definirati pojmovi održivosti i otpornosti, te ih se kontekstualizirati kroz prostor, urbanu otpornost, otpornost zajednice i kulturnu otpornost. $\mathrm{Na}$ ovaj način nastojat će se pružiti konceptualni okvir za daljnja istraživanja održivosti i otpornosti, pri čemu će pogotovo korisni biti primjeri otpornosti u zajednici.

\section{DEFINICIJE ODRŽIVOSTI I OTPORNOSTI}

Održivi razvoj proces je koji ima više definicija, a najpoznatija i najčešće upotrebljavana objavljena je u izvješću „Naša zajednička budućnost“ Komisije Ujedinjenih naroda za okoliš i razvoj iz 1987. godine, prema kojoj je održivi razvoj „onaj kojim se zadovoljavaju potrebe današnjih naraštaja, a da se pritom ne ugrožava mogućnost budućih naraštaja u zadovoljavanju njihovih potreba" (prema Bačun i sur., 2012). Ekonomski i društveni činitelji te oni vezani uz zaštitu okoliša pri tome su važni kao i upotreba resursa, smjer investicija, tehnološki razvoj i promjene koje se provode konzistentno s potrebama današnjih i budućih naraštaja. Koncept održivog razvoja definiran je dakle kao oblik razvoja koji zadovoljava potrebe sadašnjih generacija bez ugrožavanja istih mogućnosti budućih generacija (WCED, 1987). Održivost se sastoji od više dimenzija: ekonomske, ekološke, društvene (socijalne) i kulturne. „Ekonomski održiv razvoj pretpostavlja ostvarivanje gospodarskog rasta i učinkovitosti; društvena održivost postiže se ostvarivanjem zadovoljavajuće razine životnog standarda, a ekološka održivost predstavlja razvoj koji poštuje prihvatni kapacitet okoliša (engl. carrying capacity), odnosno sposobnost okoliša da podnese onečišćenje i iscrpljivanje prirodnih izvora" (Starc, 1994:73, naglasili autori). Održivim društvom pak možemo nazvati ono koje može opstati kroz generacije na fleksibilan način i kroz različite sisteme potpore. Ono postavlja informacijske, socijalne i 
institucionalne mehanizme kako bi uspostavilo uspješne standarde za rast i osiguralo da su stope rađanja i smrtnosti podjednake. Kako bi bili socijalno održivi, kombinacija populacije, kapitala i tehnologije u društvu morala bi biti uređena tako da je materijalni životni standard jednak za sve i siguran, a fizička održivost mora zadovoljavati uvjet da populacija ne prelazi prihvatne mogućnosti okoliša (Meadows i sur., 1992).

Pojam otpornosti se, kao što ćemo vidjeti, razlikuje od pojma održivosti. On u sebi sadržava prije svega bitne teme izazova klimatskih promjena i opasnih vremenskih događaja. Istraživanja otpornosti bave se procjenama rizika i adaptacijskih odgovora na te rizike, a od aktera najvećim dijelom obuhvaćaju perspektivu vlasti. Otpornost se zapravo bavi pitanjem kako se nositi s naglim, nepredvidljivim i iznenadnim promjenama u društvu, kao i šokom i krizom koje ih slijede (Kuhlicke, 2013:22). Kao takva, ona je zapravo sposobnost prilagodbe sustava ili odgovor na pojedinačne, jedinstvene i najčešće radikalne, iznenadne događaje ili procese (Mykhnenko, 2016; Olsson i sur., 2014). U tom smislu možemo je definirati kao sposobnost prilagodbe na navedene i konkretne problematične prilike.

Važno je napomenuti da se sustavi nakon nošenja s opasnim događajem ili poremećajem trebaju reorganizirati na načine da se zadrži njihova funkcija, identitet i struktura. Istovremeno se u njima održavaju i sposobnost prilagodbe, učenja i transformacije (Kabisch i sur., 2018:22). Također, otpornost je ta koja stavlja naglasak na očuvanje integriteta sustava kad se uvjeti promijene (Pelling i sur., 2015). Otpornost se zato često naziva i elastičnošću budući da zapravo pokazuje koliko se i na koji način sustav može vratiti u prethodno stanje nakon doživljenog šoka ili katastrofe.

Kako smo već napomenuli u uvodu ovog rada, a vezano uz odnos pojmova održivosti i otpornosti, potrebno je napomenuti da su održivost i otpornost koncepti otvoreni za višestruku, ponekad kontradiktornu interpretaciju koja se dijelom shvaća kao njihova snaga jer potiče rasprave između različitih disciplina. Istodobno, njihova bliskost i spomenuta otvorenost zahtijevaju pojačan napor kako bi se spriječili nesporazumi oko njihovih definicija i razgraničenja. Najvažnija razlika koju bismo mogli odrediti jest ta da koncept otpornosti stavlja veći naglasak na konkretne uznemirujuće događaje i kako se prilagoditi, nositi se s njima i oporaviti se od njih. $S$ druge strane, održivost se usredotočuje na ključne uzroke budućih poremećaja naglašavajući ih u širem i manje određenom smislu i to pretežno kroz ublažavanje klime zadržavajući istodobno i ideju socijalne sigurnosti.

$\mathrm{Na}$ temelju istraživanja otpornosti (Begg i sur., 2015; Kuhlicke, 2013) kao i urbanih transformacija i održivosti (Rink i sur., 2014; Kabisch i sur., 2018) postoje određeni elementi održivosti i otpornosti koji se smatraju različitima kod ovih dvaju koncepata (Burayidi i sur., 2020:19-23):

1. Nestabilnost, poremećaji i promjenjivost urbane sigurnosti. Kod nestabilnosti i poremećaja, otpornost stavlja veći naglasak na uznemirujuće događaje i kako se prilagoditi, nositi se s njima i oporaviti se od njih. Održivost pak istražuje temeljne uzroke budućih poremećaja naglašavajući ublažavanje klime i ideju socijalne sigurnosti;

2. Promjenjiva raspodjela odgovornosti javnih i privatnih aktera. Raspodjela se odgovornosti također određuje prilično različito. Otpornost vlastima omogućuje da odgovornost dodijele individualnoj i lokalnoj razini, a održivost uglavnom traži egalitarni pristup koji prvenstveno ističe pravo najugroženije grupe koju treba zaštititi; 
3. Normativna osnova obaju koncepata. Normativni postulat održivosti jest održanje pravednosti između različitih generacija i različitih društvenih skupina. Otpornost je neutralniji proces koji najviše ovisi o smjernicama nekih općih principa izvedenih iz ekologije (prilagodljivost i sl.), a u manjoj je mjeri zadatak koji se temelji na političkim i širim društvenim raspravama i odlukama (npr. kolika je otpornost dovoljna otpornost i sl., kao što je slučaj s održivošću);

4. Prostorno-vremenska dimenzija. Otpornost je više orijentirana na lokaciju i konkretnu situaciju, a nije posve specifična s obzirom na vremensku orijentaciju, dok održivost ima svoju dugoročnu vremensku putanju i orijentaciju.

Za kraj, možemo spomenuti i neke definicije otpornosti promatrane iz prizme društvenih znanosti. Razumijevanje se otpornosti tako odnosi na dugoročni i kratkoročni društveno-politički proces promjena, a već spomenuta elastičnost koja se često u definicijama povezuje $s$ otpornošću zapravo označava prilagodljivost, kao i sposobnost odskoka od „šokova“ koji se često odnose na prirodne katastrofe (Cretney, 2014). Teorija je otpornosti u svom trenutnom obliku stoga usko povezana s teorijom složenih adaptivnih sustava. Prema toj teoriji, modeli promjene u procesima strukturiranja označavaju sustav koji se može reorganizirati - često potaknut razdobljem brze promjene ili poremećaja - u novi režim ili sustav u kojem je dinamika različita (Levine i sur., 2012). Otpornost, iz svih navedenih definicija, možemo opisati i kao kontekstualiziranu održivost (Burayidi i sur., 2020), tj. uvjetno rečeno to je pojam manje razine općenitosti od održivosti koja posjeduje svoje konkretne prostorne i vremenske koordinate i vizije te političke i društvene ciljeve. Otpornost se pak odnosi na specifičnije situacije i prostore (lokacije) u kojima je promatramo i definiramo, orijentirajući se pretežno na vlast i lokalnu zajednicu, a bez šireg političkog i društvenog konteksta.

\subsection{Koncept otpornosti u Hrvatskoj}

Koncept otpornosti u posljednjih je nekoliko godina postao sastavni dio upravljačkih politika i popratne dokumentacije pa je tako otpornost strateški cilj prostorne i razvojne strategije, ali i posebnog nacionalnog plana oporavka i otpornosti povezanog s elementarnim nepogodama poput pandemije i potresa.

Strategija prostornog razvoja Republike Hrvatske (Marohnić-Kuzmanović i sur., 2017:160166) u kontekstu otpornosti i promjena spominje sljedeće:

1. prilagodbu klimatskim promjenama - neosporan je neposredan utjecaj na promjene i poremećaje ekosustava i kvalitetu života ljudi pojedinačno, a na razini zajednice i gospodarstva moguće je promatrati neposredne i posredne utjecaje;

2. jačanje prirodnog kapitala planiranjem razvoja zelene infrastrukture - uključivanje pitanja zelene infrastrukture u postupke planiranja temelji se na pristupu procjene zelene infrastrukture uzimajući u obzir njezin položaj, prijetnje, ograničenja, prioritete, mogućnosti i druge specifične čimbenike: geografske, okolišne, društvene, političke, gospodarske itd;

3. povećanje energetske učinkovitosti; 
4. održivo gospodarenje otpadom / radioaktivnim otpadom / mineralnim. Propisivanje i provođenje mjera za smanjenje količine otpada koji se odlaže na odlagališta, npr. smanjenje biorazgradivog otpada ponovnom uporabom, odvajanjem i recikliranjem, doprinosi ujedno smanjenju pritisaka na prostor što se odnosi na skladištenje i odlaganje otpada;

5. razvijanje održivog turizma. Poticanje povezivanja održivog turističkog razvoja s ruralnim razvojem, održivim korištenjem prirodne i kulturne baštine te zaštitom i korištenjem krajobraza u konačnici će rezultirati jačanjem izvansezonskog turizma i turističkog doživljaja cijelog teritorija $\mathrm{RH}$.

$\mathrm{U}$ recentnijem dokumentu, Nacionalna razvojna strategija $R H$ do 2030. godine (NN 13/21) identificirana je i društvena otpornost kroz stateški cilj jačanje otpornosti na krize kroz zdrav aktivan i kvalitetan život, demografsku revitalizaciju i bolji položaj obitelji te sigurnost za stabilan razvoj. Nadalje, pojam otpornosti spominje se opetovano kroz gotovo sve strateške ciljeve koji su obuhvaćeni strategijom s posebnim naglaskom na ekološku i financijsku otpornost.

Osim nove razvojne strategije, objavljen je i izuzetno opsežan dokument Nacionalni plan oporavka i otpornosti od 2021. do 2026. u kojem je poseban naglasak stavljen na otpornost povezanu s krizom izazvanom pandemijom koja traje od 2020. godine. Plan uključuje sve sektore, a definiran je kao „alat za transformaciju gospodarstva koji će omogućiti oblikovanje inovativnih politika kroz modernizaciju te digitalnu i zelenu tranziciju gospodarstva čime će povoljno utjecati na dugoročni i održiviji razvoj Hrvatske“ (Vlada Republike Hrvatske, 2021:2).

Strategije i planovi koriste meta jezik u kojemu se pojmovi poput održivosti i otpornosti najčešće dio općih ciljeva i vrlo općenitih mehanizama postizanja tih ciljeva, što je vidljivo i u ranije spomenutim nacionalnim dokumentima, stoga definicije i primjene koncepata češće možemo naći u znanstvenoistraživačkom diskursu.

U sociološkim istraživanjima u Hrvatskoj, otpornošću se bavi u kontekstu lokalnih zajednica kao što je slučaj u studiji slučaja o ribolovnoj zajednici na otoku Ugljanu gdje se konceptu otpornosti prilazi, između ostalog, kao „načinu upravljanja koji uključuje razmišljanje o otpornosti kao konstantom procesu samorefleksije i samosvijesti“ (Lukić i Tonković, 2018:2). U istraživanju Ančića, Domazeta i Župarić-Iljića (2019) autori se bave otpornošću u kontekstu društvenih nejednakosti i klase na temelju istraživanja o samoproizvodnji hrane u kojem definiraju otpornost kao „kombinirana individualna, društvena i materijalna sredstva za adaptaciju koja uključuju imovinu, mogućnosti i aktivnosti kućanstava da održe osnovnu strukturu i funkciju u svrhu prevladavanja okolišnih rizika i neprilika te zadržavanja sredstava za život i općenitu kvalitetu života" (Ančić i sur., 2019:70). Najrecentniji radovi koji se bave otpornošću povezani su s posljedicama pandemije COVID-19 i razornih potresa iz 2020. godine, koji otpornosti prilazi s obiteljskog i individualnog nivoa, zatim otpornosti organizacije te rezilijentnosti sustava (Brajdić Vuković i Doolan, 2021; Krolo i sur., 2020; Srbljinović i sur., 2020). Zanimanje za koncept otpornosti u akademskoj zajednici ne jenjava te se pregledom sažetaka s nacionalnog kongresa Hrvatskog sociološkog društva pod nazivom „Hrvatsko 
društvo i COVID-19 pandemija: Kriza kao prilika?““ (20. i 21. svibnja 2021.) može očekivati veći broj cjelovitih radova koji se temelje na istraživanju posljedica navedenih globalnih i lokalnih nepogoda (Puđak i sur., 2021; Tonković i Cepić, 2021; Božić i Srbljinović, 2020; Trako Poljak i sur., 2021). Uzimajući u obzir navedeno, definiranje i teorijsko modeliranje koncepta otpornosti na temelju kontekstualizacije i lokalizacije u svrhu implementacije socijalne otpornosti u istraživački diskurs predstavlja nužan korak u razvoju sociološkog poimanja otpornosti.

\section{URBANA OTPORNOST}

Koncept otpornosti može biti koristan za urbane planere ili upravljačke agencije kako bi se poboljšali, izgradili ili razvili kapaciteti u zajednicama, urbaniziranim područjima i čitavim sustavima koje treba pripremiti da odgovore na neočekivane događaje koji mogu predstavljati prijetnju. Gradovi su posebno izloženi takvim promjenama. Urbana otpornost zato je pogotovo važan pojam u ovom kontekstu koji je potrebno definirati. Ideja urbane otpornosti kao graničnog koncepta koji premošćuje ekologiju, planiranje i društvene znanosti rođena je u studijama urbane ekologije (Alberti i Marzluff, 2004; Pickett i sur., 2004) i od tada se razvija. U izvješću Resilience Alliance (2007) napominje se da urbanu otpornost treba usmjeriti na količinu i vrste poremećaja koje urbana područja apsorbiraju u svojoj potrazi za uravnoteženjem između urbanih i ekoloških funkcija. Ključno je naglasiti da gradovi nisu neovisni sustavi, već su otvoreni prema drugim gradovima o kojima su i ovisni te stoga možemo govoriti o međuovisnosti gradova. To znači da otpornost jednog grada ovisi o otpornosti drugog grada u skladu sa širim sustavom gradova.

Otpornost u gradovima uglavnom djeluje na gradskom nivou i bavi se održavanjem od lokalnih do regionalnih usluga ekosustava. Otpornost gradova je također bila glavna preokupacija većine urbanih ekologa (Alberti i Marzluff, 2004; Pickett i sur., 2004; Andersson, 2006; i dr.). Radi se o uskoj povezanosti s urbanim oblicima (obrascima) korištenja zemljišta $s$ jedne strane te lokalnih, prostornih i ekoloških procesa $s$ druge strane. Ona uz to uključuje sudionike poput urbanista i stanovnika, tvrtke, ali također i stambene, skvoterske i urbane socijalne pokrete zajedno s onima koji imaju znanje ili utječu na ekološke procese. Primjer je takve otpornosti grad Baltimore u Sjedinjenim Američkim Državama koji se već više od desetljeća proaktivno bavi povećavanjem vlastitih prirodnih resursa, ekološki prihvatljivom izgradnjom, smanjenjem potrošnje energije, promoviranjem recikliranja i kompostiranja, očuvanjem šuma i sl., a u svrhu smanjenja svog utjecaja na klimatske promjene. $U$ tom se smislu pojavljuju i ekološke interakcije poput vrtlarenja, poljoprivrede i šumarstva koje istovremeno udovoljavaju socijalnim potrebama, ali i poboljšavaju funkcije ekosustava (Altieri i sur., 1999; Barthel, 2006; Colding, 2007; i dr.).

Gradovi se kao sociološki sustavi suočavaju sa sve većim izazovima koje postavlja široka lepeza raznolikih stresora i šokova: klimatske promjene, rast stanovništva, urbanizacija, prirodne i ostale katastrofe, iscrpljivanje resursa. Ove se prijetnje ne mogu izbjeći i to je 
dovelo do širenja koncepta otpornosti (Renschler i sur., 2010). Zato se sve veća pažnja pridaje kako otpornosti tako i sve većem broju alata za procjenu otpornosti kao i okvira razvijenih za mjerenje otpornosti. Također, razne se aktivnosti i projekti poduzimaju za operacionaliziranje strategija ovih procjena. One su većinom usredotočene na pojedinačne sektore, ali zauzimaju i multisektorski pristup.

Postoje različiti pristupi koji obuhvaćaju ekološke, socijalne, ekonomske i institucionalne aspekte urbane otpornosti (Yamagata i Maruyama, 2016:260). U tom se smislu izdvajaju važni elementi ili značajke koje bi trebao sadržavati bilo koji urbani sustav, a koje bi u kontekstu otpornosti trebalo razvijati. To su: robusnost, stabilnost, fleksibilnost, snalažljivost, sposobnost koordinacije, raznolikost, neovisnost, povezanost i međuovisnost, sposobnost suradnje, okretnost, prilagodljivost, samoorganizacija, kreativnost i inovativnost, učinkovitost i kapital (Sharifi i Yamagata, 2016:261). Ove općenite značajke važno je naznačiti kao osnove svakog sustava koji smjera održivosti, a osim njih možemo govoriti i o različitim dimenzijama urbane otpornosti, od kojih se kao najvažnije navode:

1. materijali i resursi iz okoline koji se mogu koristiti u smislu alata u konceptu otpornosti;

2. dobrobit (engl. well-being) (u koju se ubraja, primjerice, socijalni kapital nekog društva);

3. ekonomija, tj. ekonomska osnovica i razvijenost urbanog sustava;

4. okolina i infrastruktura (engl. built environment) koje podupiru koncept otpornosti te su konstruirane s tom namjerom;

5. vlada i institucije, kao već spomenuti ključni akteri u konceptu otpornosti (Sharifi i Yamagata, 2016:261).

$\mathrm{Na}$ kraju valja napomenuti kako je otpornost usko povezana s prilagodljivosti koja je jedna od njezinih najvažnijih elemenata. Proširivanje teorije adaptivnog ciklusa (prvotno razvijene kao razumijevanje složenosti i dinamike ekosustava tj. socijalno-ekološkog sustava u urbanom sustavu) tvrdi da gradovi i infrastrukture redovito prolaze kroz četiri faze:

1. eksploataciju;

2. konzerviranje;

3. oslobođenje;

4. reorganizaciju (Gunderson i Holling, 2002).

Prijelaz iz eksploatacije u konzerviranje neke urbane strukture odvija se kroz dulje vrijeme polaganim promjenama i kroz relativno predvidljiv sustav. No, prijelaz iz oslobođenja u fazu reorganizacije označava kratko razdoblje kaotičnih promjena i velike neizvjesnosti do kojih je i došlo zbog kumulativnog nakupljanja događaja malog opsega što $s$ vremenom može dovesti do velikih transformacija. Nakon toga ponovo slijedi razdoblje normalnog funkcioniranja, usporenih promjena i relativne stabilnosti. Upravo nagli porast nepredvidljivosti može rezultirati povremenim prekoračenjem kritičnih granica urbanih sustava (Gunderson i Holling, 2002) i zato treba biti oprezan pri strukturira- 
nju i organiziranju urbane otpornosti kako bi se kroz otpornost i prilagodljivost urbani sustav mogao vratiti u prvotno stanje. Prekomjerno oslanjanje na otpornost i robusnost sustava može rezultirati nepovratnim promjenama i uzrokovati značajan gubitak u dotadašnjem funkcioniranju sustava (Yamagata i Mayurama, 2016:231) te je stoga također naglašeno važno i potrebno detaljno i pažljivo planiranje otpornosti.

Unaprjeđivanje prostorne održivosti temelji se i uglavnom na ruralno-urbanim vezama. To je važno naglasiti jer je povezanost ruralnog i urbanog u ekonomskom, kulturnom, socijalnom i ekološkom smislu temelj njihove održivosti pa su prema tome i njihovi komunikacija i kooperacija zapravo preduvjet njihove održivosti. Ovaj odnos i nužnost unaprjeđenja temelji se na harmoničnom razvoju zajednice koji ne briše identitet regija i gradova, a usmjeren je na smanjenje njihovih razlika. Europski dokumenti tako govore o urbano-ruralnom partnerstvu i o ponovnoj uspostavi urbano-ruralnih veza, posebice povezivanjem komplementarne urbane i ruralne ekonomije. Gradovi u ruralnim regijama označeni su kao integralna komponenta ruralnog razvoja, a ruralno-urbani odnos u gusto naseljenim regijama razlikuje se od takvog odnosa u rijetko naseljenim regijama (Marohnić-Kuzmanović i sur., 2017:123). U drugim razvijenim europskim zemljama već postoje različite strategije i zakoni koji teže smanjenju regionalnih razlika, no u $\mathrm{Hr}$ vatskoj je takvo planiranje još uvijek u začetku.

\section{PROSTORNA I KULTURNA OTPORNOST - LOKALIZIRANJE OTPORNOSTI}

U posljednjih nekoliko desetljeća koncept održivosti etablirao se kao dio društvenih znanosti i unatoč činjenici da je proizašao iz ekološke paradigme, danas je ekološka dimenzija samo jedan od četiri stupa održivosti te tek zajedno s ekonomskim, socijalnim i kulturnim stupom čini temelj onog što danas nazivamo održivim razvojem. $\mathrm{Na}$ sličan način možemo sagledavati i pojam otpornosti koji je pozicioniran u širi kontekst socio-ekološkog sustava zbog čega je koncept otpornosti smješten u diskurs o globalnom (najčešće kao odgovor na ekološke, elementarne ili biološke katastrofe). Međutim, treba imati na umu da kada govorimo o otpornosti socioekološkog sustava ne govorimo samo o apstraktnom sustavu na koji utječu nepredvidive i neočekivane ekološke nedaće, već govorimo i o dugoročnim izazovima koji se događaju iznutra, odnosno proizlaze iz same zajednice koju pak moramo razumijevati u globalnom, ali i nacionalnom, regionalnom i lokalnom kontekstu (Rega i Bonifazi, 2020). Philippe Bourbeau (2018) u svojoj genealogiji otpornosti naglašava da otpornost mora biti u vezi sa specifičnim kontekstom. $\mathrm{Na}$ tom tragu Bruce Glavovic i sur. (2003) govore o slojevima otpornosti koji se odnose na različite društvene aktere poput ,individue, kućanstva, zajednice, etničke zajednice ili pak na globalne" od kojih svi mogu pridonositi otpornosti ili par svojim djelovanjem oslabiti potencijalnu otpornost.

Koncept otpornosti ima porijeklo u istraživanju stabilizacije nakon specifičnog stresa ili šoka koji nastaje uslijed elementarnih nepogoda ili pak različitih bioloških i ekoloških katastrofa koje utječu na socioekološki sustav. No otpornost podrazumijeva i adaptaciju 
na specifične kratkoročne i dugoročne promjene koje su izazvane različitim društvenim faktorima primjerice demografskim, ekonomskim ili političkim. Društvene znanosti u dosadašnjim teorijskim i istraživačkim radovima skrenule su pozornost na važnost socijalne otpornosti kao specifičnog dijela šireg koncepta otpornosti, a istraživački proces je posebno fokusiran na društvene aktere kao nositelje procesa otpornosti naglašavajući društvene odnose i participacijski proces (Hernández i Harteisen, 2019). Preuzimajući osnovne postulate otpornosti definirane kroz dosadašnju ekološku paradigmu, socijalna otpornost oslanja se na postojanje širokog spektra aktera što transformira principe ekološke / okolišne otpornosti u društvene dimenzije koje Markus Keck i Patrick Sakdapolrak (2013) definiraju kroz tri kapaciteta društvenih aktera: kapacitet snalaženja, kapacitet prilagodbe i kapacitet transformacije.

Polazeći od pretpostavke da kapaciteti snalaženja, prilagodbe i transformacije imaju porijeklo u sociokulturnim vrijednostima određene zajednice, u ovom radu naglasak je na socijalnoj, ali i kulturnoj te prostornoj otpornosti koja se katalizira kroz zajednicu.

\subsection{Prostorna otpornost}

U prethodnom poglavlju ukazano je na važnost urbano-ruralnih veza kao temeljnih odrednica unaprjeđenja urbanog i ruralnog prostora što nas dovodi do prostornosti kao neodvojivog dijela diskursa o otpornosti u kontekstu urbano-ruralnih veza. Recentno promišljanje prostornosti u sociologiji rezultat je iznimnog doprinosa teoretičara dvadesetog stoljeća koji su prostornost pozicionirali kao jedan od ključnih elemenata globalne dinamike. Suvremena konceptualizacija prostora proizašla iz poststrukturalističkih teorija prostor objašnjava kao proizvod odnosa, a ne strukture. Danas prostornost podrazumijeva tokove i čvorišta i udaljava se od dihotomija poput globalno-lokalno i urbano-ruralno, shvaćajući prostor kao „teritorije postajanja koji proizvode potencijale“ kako definira Nigel Thrift (2004:88), odnosno kao „mjesto susreta gdje se odnosi isprepleću i presijecaju“ (Massey, 1991:28, naglasili autori). Sagledavajući suvremenu konceptualizaciju prostora Amin umjesto ruralno-urbano sagledava odnos grada i regije te definira taj odnos kao „mjesta heterogenosti koja su suprotstavljena na maloj prostornoj udaljenosti i kao mjesta mnogostrukih geografija pripadnosti, povezanosti i tokova“ (Amin, 2004:38).

Imajući na umu navedeno u kontekstu otpornosti potrebno je izdvojiti još jedan fenomen povezan s prostornošću u kontekstu otpornosti, a to je periferijalizacija. Unatoč procesima poput regionalne urbanizacije i rurbanizacije, postoji čitav niz prostora koji nisu na putanji prostora tokova niti su povezana s čvorištima te koja pripadaju periferiji, odnosno "fizičkim i društvenim prostorima male socijalne gustoće zbivanja, što za posljedicu ima i relativno nizak stupanj ukupne socijalne energije“ (Lay, 1998:15). Za razliku od periferije koja je stanje, periferijalizacija je vezana za „društvene odnose koji imaju prostorne implikacije“ i fokus joj je na „dinamičnom procesu kojim nastaju periferije“ (Kühn, 2015; Pezzi, i Urso, 2017). Uključivanje periferije u regionalnu prostornu dinamiku kroz lokalne ekonomske i društvene prakse važan je dio prostorne ot- 
pornosti u urbano-ruralnom kontekstu. Periferni prostori koji su vrlo često i sinonim za ruralno osjetljiviji su upravo na društvene nedaće koje dugotrajno oslabljuju potencijal specifičnog ruralnog područja. Pri tome se posebno misli na demografsko propadanje, infrastrukturno zapuštanje te fizičku i digitalnu nedostupnost. Maja Štambuk (2014) naglašava važnost temporalne i prostorne dimenzije ruralnog ističući da je upravo prostor „dinamični element“ u kojem je interakcija između zajednice i (prirodnog) okoliša mnogo značajnija nego što je to slučaj u gradu. Ukoliko se vratimo na temeljne postavke socijalne otpornosti koja se temelji na kapacitetima društvenih aktera da se snađu, prilagode i transformiraju, neaktivnost ili nedostatak društvenih aktera kao rezultat periferijalizacije dovodi do zaključka da prostorne nejednakosti dodatno otežavaju mogućnost otpornosti.

Prostornost na svim svojim razinama, dakle shvaćena teritorijalno ili pak kao rezultat društvene proizvodnje povezuje socioekološki i sociokulturni sustav. Kada je riječ o prostornoj otpornosti, prema Grazia Brunetta i Ombretta Caldarice (2020) taj spoj se najjasnije manifestira u konceptualizaciji genius loci kao jednoj od četiri dimenzije prostorne otpornosti kojom „institucije i zajednica ojačavaju sposobnost otpornosti teritorijalnog sustava" (Brunetta i Caldarice, 2020:751). Autorice naglašavaju da genius loci u kontekstu prostorne otpornosti podrazumijeva kreativnost zajednica te otvorenost institucija da prihvate aktivnosti lokalnih zajednica koje se temelje na znanju povezanom s lokalnim prostorom. Iako Brunetta i Caldarice (2020:751) prostornu otpornost definiraju kao „teritorijalni sustav suočen $s$ nesigurnošću“ fokusirajući se time na prostorni sustav i teritorij, kao i na prostorne veze, kada govorimo o prostornoj otpornosti treba imati na umu da je prostor oblikovan iz povijesnih i prirodnih elemenata, ali je istovremeno i politički proces, dakle prostorni su i društveni odnosi medureaktivni odnosno mectuovisni (Soja, 1980).

\subsection{Kulturna otpornost}

Lokalizirajući otpornost u socioprostornom sustavu, dakle izmičući makro perspektivi otpornosti kao isključivo globalnom procesu, socijalna otpornost temelji se na otpornosti zajednice, odnosno na karakteristikama i praksama otpornosti koje prema Kirsten Maclean i sur. (2014) uključuju znanje, vještine i učenje, mreže zajednice, povezanost s mjestom, infrastrukturu zajednice, raznoliku i inovativnu ekonomiju te angažirano upravljanje s posebnim naglaskom na participaciju zajednice. Razumijevanje načina na koji različiti društveni akteri ostvaruju kapacitete otpornosti povezano je s načinom na koji zajednice koriste navedene karakteristike pri čemu „kulturna aktivnosti i konstrukcija specifičnih kulturnih identiteta igra glavnu ulogu u građenju otpornosti (...)“ (Beel i sur., 2017:9). Nadalje, kultura u svojoj srži sadržava sposobnost otpora. Edward Said (1994) se u „Kulturi i imperijalizmu“ dotiče upravo kulture otpora kao načina aktivnog djelovanja u situaciji nedaće, te na primjeru imperijalizma govori o načinima na koje su kulturne inicijative djelovale po principu „preuzeti, preimenovati, nastaniti“ (engl. reclaim, rename, reinhabit) dok suvremeno djelovanje otpornosti poziva na „snalaženje, 
prilagodbu i promjenu" (engl. cope, adapt, transform) pri čemu kulturne vrijednosti i norme utječu na specifične, lokalizirane načine otpornosti.

U ranijim poglavljima objašnjen je i definiran koncept socijalne otpornosti koji predstavlja širi okvir za definiranje kulturne otpornosti gdje se naglasak prebacuje s ekološkog sustava na kulturni sustav, odnosno kako vrijednosti, norme, običaji i jezik mogu pomoći da ljudi prevladaju nedaće, bilo da je riječ o prirodnim, biološkim ili društvenim katastrofama.

Kulturna otpornost kao zasebni dio paradigme otpornosti temelji se na prepoznavanju da se otpornost ne može i ne bi trebala sagledavati mimo sociokulturne kontekstualizacije. Lucini (2014) integrira mikro, mezo i makro pristup kada je riječ o kulturnoj otpornosti iz sociološke perspektive. Na mikro razini istražuju se prakse svakodnevice i uloge koje članovi zajednice imaju te važnost identifikacije kulturnih praksi i značenja, zatim na mezo razini predlažu fokus na prakse kulturne otpornosti te na odnos praksi s organizacijskom strukturom zajednice, a na makro razini polaze od multikulturalnog konteksta te strukturalističkih i funkcionalističkih teorija koje razumijevaju zajednicu kao sustav socijalnih odnosa opet stavljajući u fokus kulturna značenja i socijalni kapital u fokusu (Slika 1).
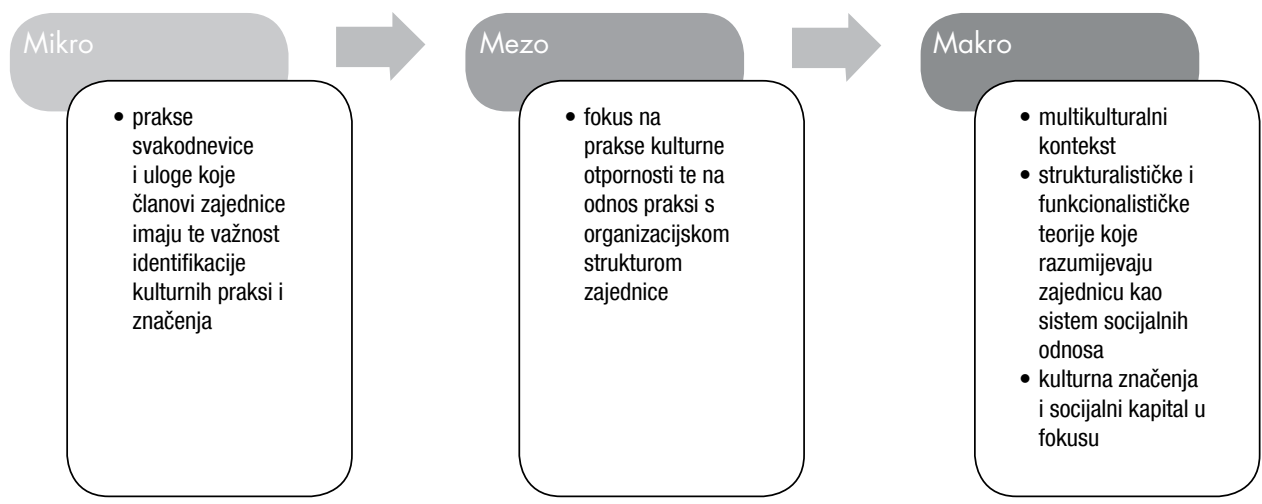

Slika 1. Prikaz modela koji obuhvaća mikro, mezo i makro pristup kulturnoj otpornosti (prema Lucini, 2014:154, uz modifikaciju autora)

U kontekstu socioekološkog sustava u koji je teorijski i empirijski uronjen koncept otpornosti naglasak je na pojednostavljivanju kompleksnih društvenih odnosa u svrhu strategijskog planiranja ili upravljanja. Todd Crane (2010) socioekološki sustav naziva „heurističkim uređajem“ koji pomaže u analizi različitih međudjelovanja, no ističe činjenicu da je za individue i zajednicu taj socioekološki sustav vrlo „materijalan, društven i simboličan", odnosno da uvođenje društvenih aktera i njihovih iskustava ili, još preciznije, uvođenje stvarnih ljudi i njihovih života u diskurs otpornosti uvodi kulturnu otpornost kao važan stup otpornosti. Imajući na umu individuu i zajednicu kao aktere Crane (2010:2) definira kulturnu otpornost kao „sposobnost da se zadrži egzistencija 
koja zadovoljava i materijalne i moralne (normativne) potrebe u slučaju velikog stresa i šoka, bilo da je okolišni, politički ekonomski ili neki drugi“.

Zajednica je bitan akter kulturne otpornosti i prema Lisi Price i Nemer Narchi kulturna je otpornost „sposobnost zajednice da se prilagodi promjeni istovremeno zadržavajući specifične strategije egzistencije tako da koriste, upravljaju i održavaju biološke i kulturne vrijednosti“ (Price i Narchi, 2018:7).

Udaljavajući se od naglaska na društvene aktere i zajednicu, Catherine Panter-Brick naglašava da su koncepti kulture i otpornosti „skliski“ koncepti, ali ukazuje na potrebu za implementacijom kulturnog $\mathrm{u}$ istraživanje otpornosti te smatra da „kulturno utemeljen pristup otpornosti identificira koji specifični kulturni ciljevi predstavljaju lajtmotiv koji pokreće putanju blagostanja prema određenom izazovu" (Panter-Brick, 2015:237). Osim toga ističe, kao i Crane, da je koncept otpornosti ne samo funkcionalan, nego i normativan koncept koji je vezan na vrijednosti i društvene aspiracije. Cornelius Holtorf (2018) se još više udaljava od zajednice pa definira kulturnu otpornost kao „kapacitet kulturnog sustava da apsorbira nedaće, nosi se s promjenama i nastavi se razvijati“ (Holtorf, 2018:639). S posebnim fokusom na kulturnu baštinu, materijalnu i nematerijalnu, ukazuje na potrebu da se kulturna otpornost sagledava kroz kontinuitet i promjenu kojoj je svrha kulturna održivost povezujući na taj način koncepte otpornosti i održivosti.

\subsection{Koncept zajednice i otpornost}

Jedna je od teza ovog rada da je upravo zajednica mjesto gdje možemo lokalizirati otpornost. U kontekstu ovog rada koji ima za cilj analizirati i strukturirati proces socijalne otpornosti zajednica u ruralno-urbanom kontinuumu iz sociološke perspektive, koncept zajednice možemo u najširem smislu definirati kao vezu između prostora i kulture, odnosno između vrijednosti i praksi kroz koju se kanalizira društvo. Kompleksnost pojma zajednice prelazi kapacitete ovog teksta, ali za potrebe lokaliziranja otpornosti kada govorimo o ruralno-urbanom kontinuumu možemo spomenuti tri sociološke konceptualizacije zajednice koje Gerard Delanty (2010:19) smatra najznačajnijim za ruralno-urbanu dihotomiju: Tönniesovu tradicionalnu zajednicu, Durkheimovu moralnu zajednicu te Cohenovu simboličku zajednicu. Unatoč razlikama, važna je poveznica ovih različitih pristupa zajednici dihotomija urbanog i ruralnog koja je kod Tönniesa i Durkheima jasno verbalizirana, dok je Cohen kritizira u fenomenu simboličkih granica koje ističe kao ključan aspekt zajednice (Delanty, 2010). Zajednica kao organsko i zbiljsko nasuprot društvu kao mehaničkom i imaginarnom kod Tönniesa ili u potpunosti suprotan prikaz zajednice kroz koncepte solidarnosti kod Durkheima (gdje zajednica odgovara konceptu mehaničke solidarnosti, a društvo konceptu organske solidarnosti) u svakom slučaju primjenjiva je na dihotomiju urbano-ruralno, no za razliku od Tönniesa, Durkheim je otvoreniji prema urbanom jer smatra da je ishodište morala u takozvanoj organskoj solidarnosti koja proizlazi iz urbanog načina života (Tönnies, 1963; Durkheim, 1972). Cohen pak zajednicu doživljava kroz kulturološke aspekte, odnosno specifičnije, kroz simbole koji definiraju granice i time usmjeravaju interakcije 
kritizirajući klasično sociološko poimanje zajednice, kao i ono koje možemo naći kod pripadnika Čikaške škole (Cohen, 1985; Delanty, 2010) zbog fokusiranja na formu i potragu za čvrstim definicijama, dok je, po Cohenu, bit zajednice iskustvo i značenje koje joj ljudi pridaju.

Vraćajući se na dihotomiju ruralno-urbano u kontekstu klasičnih socioloških teorija jasno je da se radi o suprotstavljenim fenomenima, no postmoderna paradigma počiva na uspostavljanju urbano-ruralnih veza ili mreža konstantno ukazujući na nemogućnost odvajanja ruralnog i urbanog formirajući socioprostorne koncepte poput regionalne urbanizacije ili prostornih tokova. U konstrukciji nove prostornosti koja povezuje urbano i ruralno te se koncentrira na odnos življenog i imaginarnog prostora, odnosno socijalnog prostora u kojem se odvijaju društvene prakse i isprepliću društveni odnosi, zajednica prestaje biti u vezi s paradigmom modernosti i tradicionalnosti i antipod društvenom te postaje refleksivna (Lash, 1994). Jedna od karakteristika refleksivne zajednice, prema Lashu, jest i činjenica da „oruđa i proizvodi zajednice tendiraju tome da ne budu materijalna nego apstraktna i kulturna" čime se dalje zajednica odvaja od specifičnosti fizičkog prostora (Geiger Zeman i Zeman, 2010:59).

Suvremeno poimanje zajednice isključuje tradicionalnu dihotomiju ruralno-urbano, no prostornost i mjesnost zajednice i dalje su vrlo su bitni aspekti promišljanja kojima se konstruiraju i preispituju nove dimenzije zajednica. Analizirajući neke od ključnih tipologija zajednice nameće se zaključak da koncept zajednice „leluja“ između pozicioniranja zajednice u odnosu na mjesto i u odnosu na mrežu s obzirom da se većina autora ne može odreći mjesnosti zajednice, ali osjeća potrebu za umrežavanjem zajednice u širem smislu. Jedan od takvih fenomena su tzv. „zajednice nakon mjesta“ (engl. post-place community) kojim Bradshaw (2008:13) popularizira „zajednicu kao mrežu ljudi povezanih na temelju solidarnosti, identiteta i set normi koja se nužno ne nalazi na nekom mjestu“. Međutim i sam autor, definirajući „zajednice nakon mjesta“, odmah osvještava novu mjesnost koja funkcionira kao stanovito čvorište u kojem se taj novi fenomen ostvaruje. Umreženost, kao ključan aspekt zajednice, prema Ricky Lee Allenu (1999) utječe na „lokalni kapacitet za prilagodbu na promjenu“ što je, kao što smo ranije analizirati, važan aspekt koncepta otpornosti. Lokaliziranje otpornosti događa se upravo kroz zajednicu bilo da je riječ o prostornoj ili kulturnoj lokalizaciji čime potonja obuhvaća i noviji tip zajednica (uzmimo za primjer virtualne zajednice koje su često vezane upravo kulturološkim aspektima). Imajući na umu navedeno, koncept socijalne otpornosti podrazumijeva refleksivnu zajednicu koja u svojoj definiciji počiva na mogućnosti izbora, razvučena je u prostoru što podrazumijeva i ostale tipove prostora osim fizičkog te na neprekidnom propitivanju i samootkrivanju. Drugim riječima, refleksivna zajednica već sama po sebi sadržava neke dimenzije otpornosti. „Snaga simboličkih značenja nije nešto što razlikuje zajednicu, već imaginacija i kapacitet iste da se re-kreira“ (Delanty, 2009:154). 


\section{SOCIJALNA OTPORNOST: PARTICIPACIJA U PRAKSAMA OTPORNOSTI I PRAKSE OTPORNOSTI U ZAJEDNICI}

Razumijevanje socijalne otpornosti u uskoj je vezi s konceptom zajednice kao aktera u tom dinamičnom procesu. Važnost zajednice kao jednog od ključnih aktera društva općenito nije potrebno pretjerano argumentirati, no u kontekstu socijalne otpornosti kao alata za unaprjeđenje prostora koncept zajednice gotovo je od presudne važnosti za razumijevanje suvremenih socioprostornih odnosa. Naime, otpornost. kao i održivost spadaju u univerzalne razvojne postulate / ciljeve suvremenosti, no postizanje tog cilja je, u svojoj srži, ukorijenjeno u kapacitetima snalaženja, prilagodbe i transformacije lokalnog.

Osim toga, otpornost je po svojoj definiciji sistemska što podrazumijeva multidimenzionalne veze između različitih sistema i unutar svakog pojedinačnog, posebno društvenog i ekološkog koji tvore vodeću teorijsku paradigmu otpornosti. No, sve veći broj autora ukazuje na potencijalna ograničenja socioekološkog pristupa naglašavajući potrebu za društvenom kontekstualizacijom $s$ posebnim akcentom na politička, povijesna i kulturna značenja (Keck i Sakdapolrak, 2013; Cote i Nightingale, 2012). Otvaranje prema istraživanju društvenog konteksta produbljuje mogućnosti istraživanja otpornosti unutar postojeće teorije socioekološkog sustava s obzirom da je konstrukcija i doživljaj, a samim time i otpornost od prijetnji, rizika i drugih oblika ranjivosti ukorijenjena u sociokulturnoj pozadini (Christmann i Ibert, 2012). Za socijalnu otpornost važno je istraživanje upravo društvenog konteksta kojeg su zajednica i njezini akteri te njihova prilagodljivost ključni dio. Socijalna otpornost u srži definicija u vezi je ponajprije $s$ različitim akterima, odnosno $s$ njihovim kapacitetima za prilagodbu, snalaženje i transformaciju (Keck i Sakdapolrak, 2013; Maclean i sur., 2014).

U izuzetno opsežnom pregledu definicija otpornosti s posebnim naglaskom na socijalnu otpornosti i otpornost zajednice, izvještaj Community and Regional Resilience Institute (CARRI) klasificira definicije kroz pet koncepata: otpornost kao svojstvo zajednice, otpornost kao dinamični proces, otpornost kao sposobnost adaptacije, otpornost kao putanja prema funkcionalnosti te otpornost kao sredstvo usporedivosti među zajednicama (CARRI, 2013:2). Fran Gale i Natalie Bolzan (2013) istražujući socijalnu otpornost u praksi također naglašavaju upravo neodvojivost zajednice od koncepta socijalne otpornosti koja je posebno vidljiva u kulturama u kojima je dominantna identifikacija sa sobom povezana sa zajednicom što je uobičajeno u nezapadnjačkim kulturama.

Nadalje, različiti autori pokazuju kako se u posljednje vrijeme rješenja za socijalnu otpornost koja se nadovezuje na otpornost zajednice i djelovanje svih tipova aktera većinom temelje na prirodi te kako se njoj posvećuje sva pažnja kroz nastojanje poboljšavanja otpornosti zajednica i razrješavanje višestrukih izazova s kojima se europski gradovi suočavaju (vidi Burayidi i sur., 2020). Ovakav se tip rješenja naziva „rješenja bazirana na prirodi“" (engl. nature based solutions) i zapravo se radi o namjernim intervencijama kojima se pokušava iskoristiti različita svojstva prirodnih sustava za rješavanje urbanih izazova što daje istodobno ekološku, ekonomsku i socijalnu dimenziju pri izgradnji otpornosti (Europska komisija, 2021), a odgovara i na niz urbanih izazova, od ekstre- 
mno opasnih događaja i klimatskih promjena do pitanja javnog zdravstva i socijalne nejednakosti. Urbani je rast jedan od glavnih negativnih utjecaja na ekološke probleme pa tako dolazi do nedostatka vegetacije, toplinskih otoka, smanjenja vibrantnosti grada i sl. Ključna instanca pri izgradnji socijalne otpornosti je, dakako, uključivanje građana tj. njihova participacija u nature based solutions, a njihove su prakse uglavnom povezane sa strategijama koje stvara lokalna uprava.

Burayidi i suradnici (2020:431-441) tako prikazuju primjer Melbournea koji sa svojom strategijom „urbanih šuma“ predstavlja pozitivan primjer Angažman građana se u tom primjeru pojavljuje od 2010. godine, a radi se o uključivanju stanovnika u planiranje i održavanje gradskog zelenila. Također, oni su se angažirali i oko ažuriranja strategija susjedstva (planova i područja) koja su se ticala gradskih šuma te se bave svojim estetskim preferencijama, pejzažom, dizajnom, pokrovima krošnji, sadnjom drveća. Od populacije se u ovom primjeru koncentriralo na one koje se rijetko uključivalo ili uzimalo u obzir pri planiranju: djecu, starije osobe, socijalno-ekonomski raznoliku populaciju (Bendt i sur., 2013). Cilj projekta bio je osigurati sudjelovanje građana u zajedničkom upravljanju urbanim zelenim površinama koje su postale platforme za socijalno učenje te osmisliti njihov angažman u raznim raspravama o utjecaju klimatskih promjena. Također je bitan faktor bio i njihovo što ranije i konkretnije uključivanje (Burayidi i sur., 2020). Kroz promišljanja o izgradnji socijalne otpornosti i praksi otpornosti u zajednici pojasnit ćemo i jedan primjer modela izgradnje otpornosti u zajednici Ovaj model je transformativni pristup za poticanje suradnje i izgradnju otpornosti zajednice, kao i za promicanje zdravih zajednica. To je kružni postupak procjene, spremnosti, provedbe i održivosti (Ellis i Dietz, 2017). Svaki dio procesa gradi otpornost zajednice, međutim, otpornost se zajednice neće postići dok ne budu prisutna sva područja koja djeluju međuovisno i neprestano se održavaju.

Taj model sastoji se od različitih alata, a svaki dio alata za izgradnju otpornosti zajednice usredotočen je na drugačiji dio procesa i pruža temeljne resurse za promicanje organizacijske učinkovitosti u rješavanju svakodnevnih situacija u smislu otpornosti. To su:

1. Zajedničko razumijevanje predstavlja zajednički rad na izgradnji otpornosti zajednice. Taj dio daje sažeti opis osnovnih pojmova izgradnje otpornosti zajednice kao i modele te alate za: (1) procjenu razumijevanja organizacijskih čimbenika i čimbenika zajednice koji se odnose na izgradnju zajednice i njezinu elastičnost i (2) izgradnju zajedničkog razumijevanja tih čimbenika kroz suradničko učenje, kako u obitelji tako i unutar organizacija za jačanje zajednica;

2. Stanje spremnosti. Mogućnosti sustava i pružatelja usluga koji nastoje odgovoriti i izgraditi potpore i organizacijske sposobnosti potrebne za zajednički pristup izgradnji otpornosti zajednice unutar organizacije ili mreže. Ovi alati pomažu organizacijama u: (1) procjeni njihove razine spremnosti za provedbu i (2) utvrđivanju koraka potrebnih za povećanje spremnosti za izgradnju otpornosti zajednice na temelju rezultata procjene sposobnosti pružatelja usluga, političke potpore i sistema;

3. Međusektorski partneri. Povezivanje i suradnja kroz politička partnerstva ili distribuciju resursa. Detaljno se istražuje važnost međusektorskih partnera u izgradnji 
otpornosti zajednice. Stvoreni će alati voditi organizacije u angažiranju, širenju i jačanju međusektorskih partnerstava;

4. Održavanje otpornosti zajednice. Posljednji set alata u seriji nudi put ka održavanju otpornosti zajednice $s$ alatima za istraživanje komponenata otpornosti zajednice koji uključuju: organizacijske poveznice, vodstvo građana, socijalnu potporu i povezanost s mjestom (Ellis i Dietz, 2017).

Povezivanjem navedenih elemenata, tj. alata dobivamo mogućnost uspostavljanja i izgradnje otpornosti zajednice te jasnije organiziranu strukturu implementacije bitnih elemenata koji su za takvu izgradnju potrebni. Zajedničko razumijevanje i rad na izgradnji otpornosti, stanje spremnosti na prijetnje i održavanje otpornosti putem seta alata direktno su vezani uz međusektorske partnere, tj. suradnju različitih aktera i međusobnu distribuciju različitih resursa. Participacija u praksama otpornosti te prakse otpornosti u zajednici kroz ovakve modele se mogu konkretizirati i implementirati u različitim zajednicama te također mogu pomoći i u izradi različitih strategija i planova.

\section{ZAKLJUČAK}

Kompleksnost koncepata održivosti i otpornosti sa svojom interdisciplinarnošću i multiskalarnošću istovremeno rezultiraju teorijskim i konceptualnim bogatstvom $s$ jedne strane i popularizacijom koncepata do mjere postaju samorazumljivi buzzwords s druge strane. Fokus je ovog rada na razumijevanju pojmova održivosti i otpornosti u ruralno-urbanom kontinuumu iz sociološke perspektive, a cilj je prikaz konceptualizacije socijalne otpornosti koji uključuje socioprostorne i sociokulturne elemente nužne za istraživanje otpornosti i održivosti. Važno je naglasiti i kako su koncepti održivosti i otpornosti unatoč svojim razlikama vrlo povezani budući da se koncept otpornosti uvelike i temelji na idejama održivosti. Također je važno naglasiti i važnost interdiciplinarnosti kao i multisektorstva u kontekstu otpornosti.

Polazeći od razrađenijeg i istraživanijeg koncepta održivosti koji je tijekom desetljeća evoluirao iz ekološkog u multidimenzionalan koncept koji uključuje i ekonomski, socijalni i kulturni stup održivosti, na sličan način ovdje pristupamo i konceptu otpornosti koji uz polazišnu ekološku dimenziju analiziramo kroz socijalnu, prostornu i kulturnu dimenziju. Razumijevanje otpornosti lokaliziramo unutar suvremene refleksivne zajednice pomoću prostorne i kulturne dimenzije otpornosti imajući na umu da je koncept otpornosti lokalnog karaktera te je vremenski nespecifičan za razliku od održivosti koja je u svojoj srži globalna i dugoročna, na što upozoravaju autori poput Burayidija i sur. (2020), Cretneya (2014) i Levinea i sur. (2012). Otpornost definiramo kao kontekstualiziranu održivost čime se razjašnjava međuodnos dvaju koncepata, ali se istovremeno naglašava kontekst kao važan element kada je u pitanju empirijsko istraživanje otpornosti (prema Burayidi i sur., 2020). U najširem smislu, prostor i kultura omogućavaju lokaliziranje i kontekstualizaciju, a u ovom kontekstu oni su dakle specifična podloga prilagodbe na nagle i nepredvidljive događaje (Slika 2). 
Sociološko istraživanje otpornosti i održivosti temelji se na odnosima društvenih aktera koji čine slojeve otpornosti čija uloga može biti jačanje ili slabljenje otpornosti. Upravo je zajednica mjesto u kojem djeluje širok spektar društvenih aktera čija participacija u praksama otpornosti ovisi o prostornim i kulturološkim aspektima (Allen, 1999; Keck i Sakdapolrak, 2013). Istraživanje socioprostornog i sociokulturnog konteksta produbljuje mogućnosti istraživanja, ali i razumijevanja kapaciteta otpornosti što treba uzeti u obzir prilikom izrade indikatora i strategija koje su nerijetko glavni istraživački i upravljački interes.

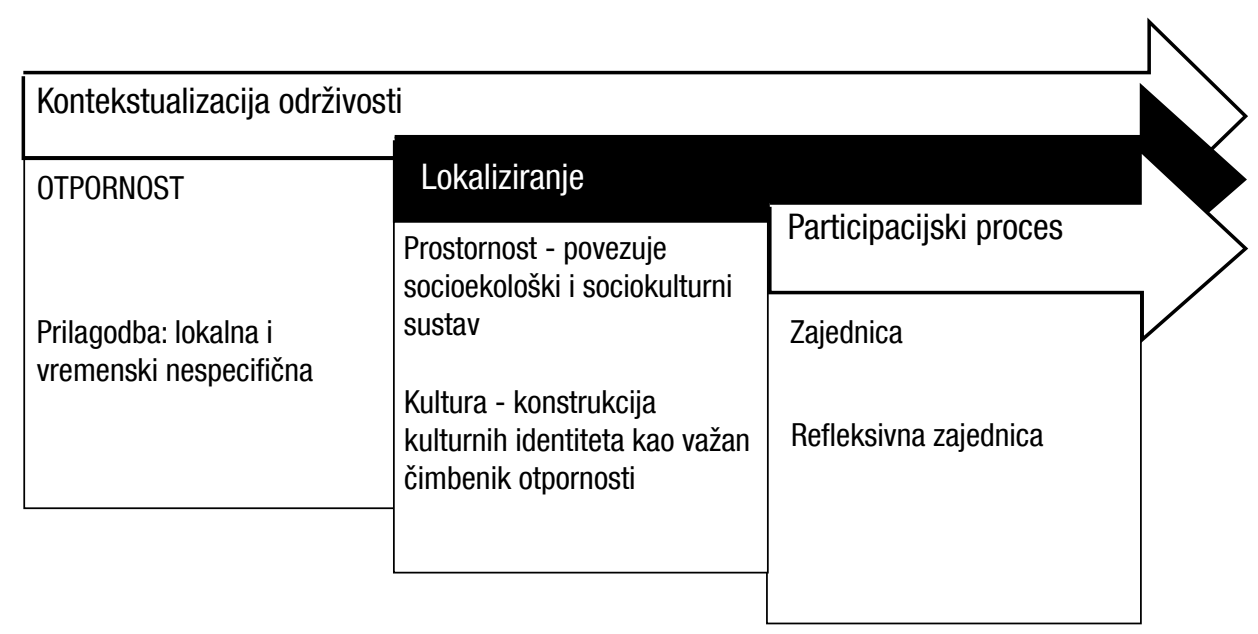

Slika 2. Prikaz konceptualizacije socijalne otpornosti (Izvor: autorice)

Kroz primjere otpornosti u zajednici možemo vidjeti ne samo participacijski proces na djelu, već i načine na koje se građani i stanovnici mogu uključiti u procese participacije, istodobno sudjelujući u konkretnim akcijama u svom gradu i u jačanju otpornosti koje su oni ključan dio kao što je vidljivo u modelu izgradnje otpornosti zajednica (prema Ellis i Dietz, 2017). Buduća se istraživanja otpornosti mogu i trebaju temeljiti upravo na različitim modelima i načinima na koje zajednice mogu biti nositelji otpornosti i na koje se reorganizacija tj. povratak društva u normalano funkcioniranje nakon prirodnih i ostalih šokova može jednostavnije i brže ostvariti. Modeli otpornosti temelje se upravo na suradnji, kako unutar same zajednice stanovnika (građana), tako i između različitih aktera (stručnih, ekonomskih, političkih i građana) koji samo zajedničkim djelovanjem mogu uspostaviti kvalitetne i vrijedne modele kako ruralne tako i urbane otpornosti. 


\section{LITERATURA}

Alberti, M. i Marzluff, J. M. (2004). Ecological Resilience in Urban Ecosystems: Linking Urban Patterns to Human and Ecological Functions. Urban Ecosystems, 7: 241-265.

Allen, R. L. (1999). The Socio-Spatial Making and Marking of 'Us': Toward a Critical Postmodern Spatial Theory of Difference and Community. Social Identities: Journal for the Study of Race, Nation and Culture, 5(3): 249-277.

Altieri, M., Nelso Companioni, A., Cañizares, K., Murphy, C., Rosset, P., Bourque, M. i Nicholls, C. I. (1999). The Greening of the "Barrios": Urban Agriculture for Food Security in Cuba. Agriculture and Human Values 16: 131-140.

Amin, A. (2004). Regions Unbound: Towards a New Politics of Place. Geografisker Annaler, 86B: 33-44.

Ančić, B., Domazet, M. i Župarić-Iljić, D. (2019). "For My Health and for My Friends": Exploring Motivation, Sharing, Environmentalism, Resilience and Class Structure of Food Self- Provisioning. Geoforum, 106: 68-77.

Andersson, E. (2006). Urban Landscapes and Sustainable Cities. Ecology and Sociology, 11(1): 34 .

Bačun, D., Matešić, M. i Omazić, M. A. (2012). Leksikon održivog razvoja. Zagreb: Hrvatski poslovni savjet za održivi razvoj.

Barthel, S. (2006). Sustaining Urban Ecosystem Services with Local Stewards Participation in Stockholm (Sweden). U: Tress, B., Tress, G., Fry, G. i Opdam, P. (ur.), From Landscape Research to Landscape Planning, Aspects of Integration, Education and Application (str. 305-320). Dordrecht: Springer.

Beel, D. E., Wallace, C. D., Webster, G., Nguyen, H., Tait, E., MacLeod, M., i Mellish, C. (2017). Cultural Resilience: The Production of Rural community Heritage, Digital Archives and the Role of Colunteers. Journal of Rural Studies, 54: 459-468.

Begg, C., Walker, G. i Kuhlicke, C. (2015). Localism and Food Risk Management in England: The Creation of New Inequalities? Environmental Planning C: Government and Policy, 33(4): 685-702.

Bendt, P., Barthel, S., i Colding, J. (2013). Civic Greening and Environmental Learning in Public- Access Community Gardens in Berlin. Landscape Urban Planning, 109(1): 18-30.

Bourbeau, P. (2018). A Genealogy of Resilience. International Political Sociology, 12(1): 19-35.

Bradshaw, T. K. (2008). The Post-Place Community: Contributions to the Debate About the Definition of Community. Community Development, 39(1): 5-16

Brajdić Vuković, M., i Doolan, K. (2021). Očaj i sreća u doba nesreće: raznolikost ženskih doživljaja karantene za vrijeme COVID-19 pandemije. Sociologija i prostor, 59(219): 241-265.

Brunetta G. i Caldarice O. (2020). Spatial Resilience in Planning: Meanings, Challenges, and Perspectives for Urban Transition. U: Leal Filho, W., Azul, A. M., Brandli, 
L., Özuyar P. G. i Wall T. (ur.), Sustainable Cities and Communities. Encyclopedia of the UN Sustainable Development Goals (str. 1-12). Cambridge: Springer.

Burayidi, M. A., Allen, A., Twigg, J. i Wamsler, C. (2020). The Routledge Handbook of Urban Resilience. London i New York: Routledge.

Christmann, G. i Ibert, O. (2012). Vulnerability and Resilience in a Socio-Spatial Perspective. Raumforschung und Raumordnung, 70: 259-272.

Colding, J. (2007). 'Ecological Land-Use Complementation' for Building Resilience in Urban Ecosystems. Landscape and Urban Planning, 81(1-2): 46-55.

Community and Regional Resilience Institute (CARRI) (2013). Definitions of Community Resilience: An Analysis. A CARRI report. Oak Ridge, TN: Community and Regional Resilience Institute.

Cote, M. i Nightingale, A. J. (2012). Resilience Thinking Meets Social Theory: Situating Social Change in Socio-Ecological Systems (SES) Research. Progress in Human Geography, 36(4): 475-489.

Crane, T. A. (2010). Of Models and Meanings: Cultural Resilience in Social-Ecological Systems. Ecology and Society, 15(4): 19.

Cretney, R. (2014). Resilience for Whom? Emerging Critical Geographies of Socio-Ecological Resilience. Geography Compass, 8(9): 627-640.

Delanty, G. (2010). Community. Routledge: London

Durkheim, E. (1972). Emile Durkheim: Selected Writings. Cambridge: Cambridge University Press.

Ellis, W. R. i Dietz, W. H. (2017). A New Framework for Addressing Adverse Childhood and Community Experiences: The Building Community Resilience Modael. Academic Pediatrics, 17(7): 86-93.

Europska komisija (2021). Nature-based solutions research policy. URL: https:// ec.europa.eu/info/research-and-innovation/research-area/environment/nature- based-solutions/research-policy_en (07.02.2021.)

Gale, F. i Bolzan, N. (2013). Social Resilience: Challenging Neo-Colonial Thinking and Practices Around 'Risk'. Journal of Youth Studies, 16(2): 257-271.

Geiger Zeman, M. i Zeman, Z. (2010). Uvod u sociologiju (održivih) zajednica. Zagreb: Institut društvenih znanosti Ivo Pilar.

Glavovic, B. C., Scheyvens, R. i Overton, J. (2003). Waves of Adversity, Layers of Resilience: Exploring the Sustainable Livelihoods Approach. U: Storey, D., Overton, J. i. Nowak, B. (ur.), Contesting Development: Pathways to Better Practice, Proceedings of the Third Biennial Conference of the Aotearoa New Zealand (str. 89-293). Palmerston North: Institute of Development Studies.

Gunderson L. H. i Holling C. S. (2002). Panarchy: Understanding Transformations in Human and Natural Systems. Washington, DC: Island Press.

Hernández, A. A. i Harteisen, U. (2019). A Proposed Framework for Rural Resilience - How can Peripheral Village Communities in Europe Shape Change? AGER Journal of Depopulation and Rural Development Studies, 27: 1-35. DOI: 10.4422/ ager.2019.05. 
Holtorf, C. (2018). Embracing Change: How Cultural Resiliencies Increased Through Cultural Heritage. World Archaeology, 50(4): 639-650

Jabareen, Y. (2013.) Planning The Resilient City: Concepts and Strategies for Coping With Climate Change and Environmental Risk. Cities, 31: 220-229.

Kabisch, S., Koch, F., Gawel, E., Haase, A., Knapp, S., Krellenberg, K., Nivala, J. i Zehnsdorf, A. (2018). Urban Transformations Sustainable Urban Development Through Resource Effciency, Quality of Life and Resilience. Cham: Springer International Publishing.

Keck, M. i Sakdapolrak, P. (2013). What is Social Resilience? Lessons Learned and Ways Forward. Erdkunde, 67(1): 5-19.

Krolo, K., Tonković, Ž., Vidović, D. i Žuvela, A. (2020). Utjecaj pandemije COVID-19 $i$ zagrebačkog potresa na OCD-e u suvremenoj kulturi i umjetnosti: rezultati testne faze istraživanja. Zagreb: Biblioteka „Kultura nova“.

Kuhlicke, C. (2013). Resilience: A Capacity and a Myth: Findings from an In-Depth Case Study in Disaster Management Research. Natural Hazards, 67(1): 61-67.

Kühn, M. (2015). Peripheralization: Theoretical Concepts Explaining Socio-Spatial Inequalities. European Planning Studies, 23(2): 367-378.

Lash, S. (1994). Reflexivity and its Doubles: Structures, Aesthetics, Community. U: Beck, U., Giddens, A. i Lash, S. (ur.), Reflexive Modernization: Politics, Tradition and Aesthetics in the Modern SocialOrder (str. 110-173). Cambridge: Polity Press.

Lay, V. (1998). Teorijske, društvene i političke neprilike s periferijom. U: Rogić, I. i Štambuk, M. (ur.), Duge sjene periferije (str. 13-40). Zagreb: Institut za društvene znanosti Ivo Pilar.

Levine, S., Pain, A., Bailey, S. i Fan, L. (2012). The Relevance of "Resilience"? London: Overseas Development Institute.

Lucini, B. (2014). Multicultural Approaches to Disaster and Cultural Resilience. How to Consider Them to Improve Disaster Management And Prevention: The Italian Case of Two Earthquakes. Procedia Economics and Finance, 18: 151-156

Lukić, A. i Tonković, Ž. (2018). Fisheries-Dependent Community - Obstacle or Opportunity for Further Development? A Case Study of Kali in Croatia. Marine Policy, 100: 116-121

Maclean K., Cuthill M. i Ross H. (2014). Six Attributes of Social Resilience. Journal of Environmental Planning and Management 57(1): 144-156.

Marohnić-Kuzmanović, V., Matković, I. i Korlaet, A. (ur.) (2017). Strategija prostornog razvoja Republike Hrvatske. Zagreb: Hrvatski zavod za prostorni razvoj.

Massey, D. (1991). A Global Sense of Place. Marxism Today, 38: 24-29.

Meadows, D. H., Meadows, D. L., i Randers, J. (1992). Beyond the Limits. White River Junction, VT: Chelsea Green.

Mykhnenko, V. (2016). Resilience: A Right-Wingers' Ploy? In: Springer, S., Birch, K. i MacLeavy, J. (ur.), The Handvolume of Neoliberalism (str. 190-206). Abingdon i New York: Routledge.

Nacionalna razvojna strategija Republike Hrvatske do 2030. godine. Narodne novine, $13 / 21$. 
Olsson, P., Galaz, V., i Boonstra, W. J. (2014). Sustainability Transformations: A Resilience Perspective. Ecology and Sociology, 19(4): 1.

Panter-Brick, C. (2015). Culture and Resilience: Next Steps for Theory and Practice. U: Theron, L. C., Liebenberg, L. i Ungar, M. (ur.), Youth Resilience and Culture: Commonalities and Complexities (str. 233-244). Berlin: Springer.

Pelling, M., O'Brien, K. i Matyas D. (2015). Adaptation and Transformation. Climate Change, 133(1): 113-127.

Price, N., i Narchi, E. (2018). Coastal Heritage and Cultural Resilience. Berlin: Springer.

Pezzi, M. G. i Urso, G. (2017). Coping with Peripherality: Local Resilience Between Policies and Practices (Editorial Note). Italian Journal of Planning Practice, 7(1): 1-23.

Pickett, S. T., Cadenasso, M. L. i Grove, J. M. (2004). Resilient Cities: Meaning, Models, and Metaphor for Integrating the Ecological, Socio-Economic, and Planning Realms. Landscape and Urban Planning, 69(4): 369-384.

Pirlone, F., Spadaro, I. i Candia, S. (2020). More Resilient Cities to Face Higher Risks. The Case of Genoa. Sustainability, 12(12): 4825. DOI: 10.3390/su12124825.

Rega, C. i Bonifazi, A. (2020). The Rise of Resilience in Spatial Planning: A Journey Through Disciplinary Boundaries and Contested Practices. Sustainability, 12(18): 7277. DOI: $10.3390 /$ su 12187277.

Renschler, C. S., Frazier, A., Arendt, L., Cimellaro, G. P., Reinhorn, A. M., i Bruneau, M. (2010).A Framework for Defining and Measuring Resilience at the Community Scale: The PEOPLES Resilience Framework. MCEER Technical Report. Buffalo, NY: MCEER.

Resilience Alliance (2007). A Research Prospectus for Urban Resilience. A Resilience Alliance Initiative for Transitioning Urban Systems towards Sustainable Future. Canberra: CSIRO, Phoenix, AZ: Arizona State University; Stockholm: Stockholm University. URL: https://issuu.com/getresilient/docs/1172764197_urbanresilienceresearchprospectusv7feb0 (07.02.2021.)

Rink, D., Couch, C., Haase, A., Krzysztofk, R., Nadolu, B. i Rumpel, P. (2014). The Governance of Urban Shrinkage in Cities of Post-Socialist Europe: Policies, Strategies and Actors. Urban Research and Practice, 7(3):258-277.

Said, E. (1994). Culture and Imperialism. New York: Knopf.

Sharifi, A. i Yamagata, Y. (2016). Principles and Criteria for Assessing Urban Energy Resilience: A Literature Review. Renewable and Sustainable Energy Reviews, 60: 1654-1677.

Soja, E. W. (1980). The Socio-Spatial Dialectic. Annals of the Association of American Geographers, 70(2): 207-225.

Starc, N. (1994). Razvoj, održivost i ocjena ulagačkih pothvata. U: Klarić, Z. (ur.), Prema održivom razvitku turizma u Hrvatskoj: zbornik radova (str. 67-81). Zagreb: Institut za turizam.

Srbljinović, A., Božić, J. i Fath, B. D. (2020). Croatian Crisis Management System’s Response to COVID-19 Pandemic Through the Lens of a Systemic Resilience Model. Interdisciplinary Description of Complex Systems, 18(4): 408-424. 
Srbljinović, A. i Božić, J. (2020). Ima li sustavnosti u hrvatskom sustavu upravljanja korona- krizom? - Pogled iz perspektive Fath-Dean-Katzmairovog modela društvene rezilijentnosti. U: Hrvatski politološki razgovori 2020.: Politika u doba pandemije zbirka sažetaka (str. 3). Zagreb: Fakultet političkih znanosti.

Štambuk, M. (2014). Lica nigdine: Društveni i prostorni okvir razvitka hrvatskog sela. Zagreb: Institut za društvene znanosti Ivo Pilar.

Thrift, N. (2004). Summoning Life. U: Cloke, P., Crag, P. i Goodwin, M. (ur.), Envisioning Human Geographies (str. 81-103). London: Arnold.

Tonković, Ž. i Cepić, D. (2021). Obrasci društvenosti i izvori potpore tijekom pandemije. U: Primorac, J., Kuti, S. i Marelić, M. (ur.), Hrvatsko društvo i COVID-19 pandemija: Kriza kao prilika? (str. 51). VIII. nacionalni kongres Hrvatskog sociološkog društva - knjiga sažetaka. Zagreb: Hrvatsko sociološko društvo.

Tönnies, F. (1963). Community and Society. New York: Harper and Row.

Trako Poljak, T., Žažar, K., Puđak, J. i Jež Rogelj, M. (2021). Kapaciteti otpornosti hrvatskih ruralnih područja kao socijalno-ekoloških sustava. U: Primorac, J., Kuti, S. i Marelić, M. (ur.), Hrvatsko društvo i COVID-19 pandemija: Kriza kao prilika? VIII. nacionalni kongres Hrvatskog sociološkog društva - knjiga sažetaka (str. 56). Zagreb: Hrvatsko sociološko društvo.

Vlada Republike Hrvatske (2021). Nacionalni plan oporavka i otpornosti od 2021. do 2026. Zagreb: Vlada Republike Hrvatske.

Vukić, J., Balić, A., Bilić, J., Kalinić, A., Nekić, M., Štih, E. i Rajčić, L. (2020). Digitalizacija kao alat za jačanje otpornosti lokalnih zajednica. U: Svržnjak, K. i Čehić, A. (ur.), Knjiga sažetaka II. međunarodnog stručno-znanstvenog skupa - Inovacije: Jamstvo budućnosti agrobiznisa u Hrvatskoj. Zagreb: Hrvatsko agronomsko društvo.

World Commission on Environment and Development (WCED) (1987). Our Common Future. Oxford, NY: Oxford University Press.

Yamagata, Y. i Mayurama, H. (ur.) (2016). Urban Resilience. A Transformative Approach. Cham: Springer International Publishing. 


\title{
SOCIO-SPATIAL APPROACH TO DEFINING AND RESEARCHING RESILIENCE AND SUSTAINABILITY
}

\author{
Jelena Zlatar Gamberožić, Sara Ursić and Jana Vukić
}

\begin{abstract}
In recent decades, the concept of sustainability has become an integral part of the social sciences. Despite the fact that it arose from the ecological paradigm, the ecological dimension is only one of the four pillars of sustainability, alongside the economic, social and cultural dimensions, which together constitute what we today call sustainable development. In a similar way, we can observe the concept of resilience, positioned within the broader notion of the socio-ecological system, which is why it is often used in the responses to environmental, natural or biological disasters. The primary purpose of the analysis and evaluation of the concepts of resilience and sustainability in this paper is to attempt to set an integrative theoretical framework for the study of urban and rural areas, as well as local communities from a sociological perspective. The definition and analysis of these concepts, delimitation of their differences, and reflection on urban resilience, opens up the possibility of a more detailed and concrete research of resilience. Understanding spatial, social and cultural resilience is closely linked to the concept of community as an actor in this dynamic process. Especially in the context of social resilience as a tool for improving (rural and urban) space, the concept of community is crucial for understanding contemporary socio-spatial relations. At the same time, the spatiality and locality of the community are very important in re-thinking and re-examining some new dimensions of communities. The localization of resilience and sustainability happens precisely by means of the community, whether it is a spatial or cultural localization.
\end{abstract}

Keywords: sustainability, urban resilience, spatial resilience, cultural resilience, community resilience

\section{DER SOZIALRÄUMLICHE ANSATZ BEIM DEFINIEREN UND ERFORSCHEN DER WIDERSTANDSFÄHIGKEIT UND NACHHALTIGKEIT}

\author{
Jelena Zlatar Gamberožić, Sara Ursić und Jana Vukić
}

\section{Zusammenfassung}

In den letzten Jahrzehnten hat sich das Konzeprt der Nachhaltigkeit als ein Teil der sozialen Wissenschaften etabliert, und obwohl es von der ökologischen Paradigma stammt, ist seine ökologische Dimension nur eine der vier Säulen der Nachhaltigkeit, erst mit der ökonomischen, sozialen und kulturellen Säule zusammen bildet es das Fundament dessen, was wir heutzutage die nachhaltige Entwicklung nennen. Auf eine ähnliche Art und Weise können wir den, in einem weiteren Kontext des sozialökologischen Systems positionierten Begriff der Widerstandsfähigkeit betrachten, den man oft als eine Antwort auf ökologische, biologische oder Elementarkatastrophen benutzt. Der vorrängige Zweck der Analyse und Evaluation der Konzepte der Widerstandsfähigkeit und Nachhaltigkeit in dieser Arbeit ist ein Versuch, einen integrativen theoretischen Rahmen zur Erforschung von urbanen und ruralen Räumen und lokalen Gemeinschaften aus der soziologischen Perspektive zu setzen. Durch das Definieren und die Analyse dieser Konzepte, durch die Abgrenzung der Unterschiede zwischen ihnen und das Verständnis der urbanen Resilienz, eröffnet sich die Möglichkeit einer detaillierteren und konkreteren Forschung der Widerstandsfähigkeit. Das Verstehen der räumlichen, sozialen und kulturellen Widerstandsfähigkeit ist eng mit dem Konzept der Gemeinschaft als Akteur in diesem dynamischen Prozess verbunden. Gerade im Kontext der sozialen Widerstandsfähigkeit, als Werkzeug zur Förderung des (ruralen und urbanen) Raums, ist das Konzept der Gemeinschaft zum Verständnis zeitgenössischer sozial-räumlichen Beziehungen von entscheidender Bedeutung. Dabei sind Räumlichkeit und Lokalität der Gemeinschaft wesentliche Aspekte beim Umdenken und der Nachprüfung 
von neuen Dimensionen der Gemeinschaften. Die Lokalisierung der Widerstandsfähigkeit und Nachhaltigkeit geschieht gerade diurch die Gemeinschaft, sei es eine räumliche oder eine kulturelle Lokalisierung.

Schlüsselwörter: Nachhaltigkeit, urbane Resilienz, räumliche Widerstandsfähigkeit, kulturelle Widerstandsfähigkeit, Widerstandsfähigkeit der Gemeinschaften 